

Politik Felsefe Dergisi

Journal of Political Philosophy

\title{
The Current Meaning of Jacques Rancière's Political Thought (Interview with Oliver Davis)
}

\section{Oliver DAVIS* Zeliha DIȘCí**}

What does Rancière's political thought mean today? We interviewed to answer this important question with Oliver Davis, who works in the Department of French Studies at Warwick University and is known for his studies on Rancière.

Zeliha Dişci (ZD): From Rancière's perspective, how should we interpret the social movements we have been experiencing since the 2000s? One of the most important criticisms directed at Rancière is that what he really focuses on in a political experience is the encounter

\footnotetext{
${ }^{*}$ Prof. Dr. I Prof.

Fransız Çalışmaları Bölümü, Modern Diller ve Kültürler Okulu, Warvick Üniversitesi I French Studies, School of Modern Languages and Cultures, Warvick University.

${ }^{* *}$ Dr. Öğr. Üyesi I Assist. Prof.

Siyaset Bilimi ve Kamu Yönetimi Bölümü, Kafkas Üniversitesi I Political Science and Public Administration Department, Kafkas University.

zeliha.disci@gmail.com

Orcid Id: 0000-0001-5650-680X

Doi: http://dx.doi.org/10.47614/arete.pfd.42

Davis, O. / Dişci, Z. (2021). The Current Meaning of Jacques Rancière's Political Thought (Interview with Oliver Davis). Arete Politik Felsefe Dergisi. 1(2). 100-106.
} 
between police and politics, that is, the conflict, but he has no imagination about how life will be organized after the conflict.

Oliver Davis (OD): I can't speak for Jacques Rancière, of course, but I can try to respond to your questions as someone who spent several years thinking about his work before moving on to other areas. This interview comes at a good moment for me because very recently I have been pausing these other projects to reflect back on his thought, on what I made of it and what it has made of me. To start at the end of your question, I would agree that as a thinker of politics Rancière certainly doesn't choose to direct his imagination at long-term organization, 'policy' - the shape of the polis, polity or police order, so to speak. His thought is not on the side of organization or administration. You can choose to see that as a criticism, or weakness, as your question implies. However, I would suggest it is worth reflecting on the way in which philosophy has been haunted since its inception by the administrative or organizational, has always been on the point of tipping over into technocratic ordering. From a critical perspective, philosophy's juridicism - its entwinement with the juridical forms of bourgeois state organization - is obviously a problem but, in a way, I would suggest that this problematic imbrication with the juridical, which is clearest perhaps in Kant and Hegel, masks an even less tractable entanglement with the administrative. Rancière can come across as naive, as fetishising the moment of interruption, even as juvenile or 'irresponsible' in a penchant for the beginnings and the emergence of things, as unwilling to envisage shouldering the more 'adult' burden of their inscription, but I would say that these criticisms betray an unwillingness to acknowledge the full extent of philosophy's technocratic temptation. Your question asked first about the social movements we have been experiencing from the 2000s, which is quite a wide and heterogeneous array, as no doubt are the subjects of those experiences. As you know, when the Berlin Wall fell in 1989 right-wing ideologues triumphantly proclaimed the 'End of History' and the emergence of a new order of smoothly consensual global ordering. Rancière was quick to sense the hollow ring of this triumphalism and to identify and critique the consensualism of this new era. I would call this the era of 'governance', in Wendy Brown's (2015) critical sense of that term - and her critique, which resonates with Rancière's work without being obviously indebted to it, is all the powerful for redeploying precisely the same term so often used in this order's acts of self-description, as manifested not only at the loftier heights of global geopolitics but also in almost every organizational entity from NGOs to universities to wildlife parks - and this would be the era in which neoliberal capitalism's largley underrecognized practices of administrative ordering have reshaped our shared social and political world, to a large extent 
without these 'termitelike' acts of reorganising ever having explicitly appeared on the horizon of democratic debate, or ever having been constituted as a problem (Brown 2015). In other words, much of this work has been undertaken in administrative, organisational, technical what used commonly to be termed 'bureaucratic' - ways but we are only just beginning to apprehend the cumulative effects.

ZD: The Police is a concept that has great importance in terms of political philosophy and has come from ancient Greece to the present day. Although there are different forms of usage, we see that it has become the focus of contemporary political debates with Rancière. Do you think that Rancière made a difference in his evaluation of the police concept?

OD: Apart from the opposition between politics and the police, which can perhaps best be understood in terms of its binary technics, as a wilfully primitive either/or operator, designed to split open the homogenous order of 'governance' and 'consensus' - in other words, as a political technology - I do not see Rancière as a thinker of the police in any general sense and perhaps this is a problem. There are some excellent critical accounts of the history of the police, in the wide sense of social organisation derived from the Greek, and relatedly of 'police science' as a form of social organising, for instance Mark Neocleous's The Fabrication of Social Order: A Critical Theory of Police Power (2000), which can be read productively alongside Rancière's work and which I think Rancière's work helps to illuminate, yet Rancière himself manifestly isn't interested in doing this kind of analytical political history. Where I would say that his political work could most benefit from supplement is in a detailed technical understanding of the way in which neoliberal capitalism's machinic bureaucracies of governance actually function today: for instance, the way that algorithmically-driven operations of ranking, ie. hierachising, instantiating micro-inequalities, here, there and everywhere, are reordering the world around us. One can only get to this, however, by way of a conceptual and practical understanding of the forms bureaucracy takes today - and here I would recommend the late David Graeber's work, in particular The Utopia of Rules: On Technology, Stupidity, and the Secret Joys of Bureaucracy (2015).

ZD: While contemporary thinkers develop their ideas, they often engage in dialogue with different philosophers (before their time generally). In this context, one of the basic judgments about Gilles Deleuze is that he did not deal with thinkers such as Spinoza, Kant etc. in their entirety, and instrumentalized them in terms of his own philosophy and detract their concepts from their meanings. Can we make a similar judgment to Rancière, who used very important 
thinkers of political philosophy such as Plato, Aristotle and Hobbes while constituting his own philosophy?

OD: The anxiety about whether or not particular figures in the history of philosophy have been adequately 'covered' in its 'entirety' seems to me quaintly and distinctly administrative, indeed to testify to the administrating penchant in philosophy as it is actually taught and practised. Certainly, in Deleuze's work, but also in Foucault's and Rancière's, tangential, appropriative, resignifying and determinedly partial readings are almost to be expected. Within the French Contintental tradition Derrida is a contrasting figure in that sense: the entirety of the corpus is generally still important and his readings often range voraciously over that entire body of work, even though his many ways of picking out elements from that work seem anything but adminstrative. There is too much scholarship today that is essentially antiquarian in its desire to track down and inventory every last sketch and note - some of this has to do with the way basic research in the humanities is funded and recognised, unfortunately - and treatments of the philosophers just mentioned in these terms strike me as especially misguided.

ZD: Can we say that you have brought an interpretation to Rancière's concept of politics with the concept of 'anti-police' you used in your work titled "The Anti-Police of Mai '68 Fifty Years On"? Because in Rancière, politics finds its meaning through activities that appear within the police but open up the counting forms, which we can call "police activities", in discussion.

OD: Yes and no: I didn't really present that special issue or the article I wrote for it in Rancierian terms. My article is primarily historical and belongs to the body of work I produced after moving away from Rancière. Nevertheless, when I set that particular focus for the special issue I was certainly influenced by the presence of Mai '68 in Rancière's work and perhaps more especially by Kristin's Ross's expressly Rancierian account of 'the events' and, especially, her discussion of certain types of historiographical practice and their related forms of authorized historical intelligibility as policing practices. I found it ironic in looking at the history of the history of Mai ' 68 that some of the very first research on the events took place while they were still happening and took the form of activist-researchers' investigations of police brutality, yet in the intervening years - and as I am sure you know there has been a lot written about that moment in the half-century since - the police and the protestors' concept and practice of an 'anti-police' had largely been eclipsed by other concerns. Nevertheless, my article is much more historical than I am perhaps making it sound, and even took me to the police archives. What I principally discovered is that historians failed to recognize the full extent of the police forces mobilized against demonstrators - les forces de l'ordre, as French aptly calls 
the different particular institutional units that English-speakers tend simply to call 'the police' - and especially the significant role of plain-clothes commando units of right-wing and far-right militias associated with the SAC (a Gaullist political organisation) and probably directed by Jacques Foccart. These were essentially shock troops deployed secretively alongside the police in what could be characterized as a counterinsurgency operation. However, my approach was less indebted to Rancière and more to thought around '(in)security' developed by Critical Security Studies.

ZD: Where do you position Rancière's thoughts on the politics and the political in contemporary French thought? I ask this question because when we think of the politics with disruptive/interruptive activities, the motif of interruption is very common in contemporary French thinkers from twentieth century to the present.

OD: I am afraid I have ceased to understand the appeal of the type of classificatory survey you seem to be inviting me to undertake of contemporary French thought. I am not sure 'interruption' is really a 'motif'; rather, a fairly high-level abstraction from a wide range of particular concerns and situated inquiries. Of course one can point to affinities within 'French thought today' but as my comments earlier in this interview might suggest, I tend to read Rancière more alongside radical thinkers of politics from different national-cultural locations, for instance, Wendy Brown, or David Graeber. Furthermore, when you look historically at the development of Rancière's thought, the encounter with the English historian E.P. Thompson was clearly very significant and Rancière has always read widely and unexpectedly (I recall the remark in The Method of Equality (2016) about the encounter with Gauny being more significant for him than reading Lacan or Heidegger). I wouldn't personally seek to reinscribe him within the confines of contemporary thought of the French left, though there are plenty of good books which do a good job of this.

ZD: Can we see the discourse on equality in The Ignorant Schoolmaster (1987) as an improved version of the modern understanding of equality? I remember Rancière being criticized by Peter Hallward (2005) on this. According to Hallward, Rancière "does not adequately embody the notion of equality in which the singular clings to the universal." I guess, this means that Rancière's understanding of equality still remains at the mystical level, doesn't it?

OD: This follows on quite neatly from your preceding question: if one tries to contrast Rancière with thinkers who might - generationally, biographically, institutionally - be assumed 
to be his natural comparators, for instance with Alain Badiou, then this kind of verdict readily emerges. I have great respect for Peter as a philosopher and interpreter but I would suggest that this judgment of Rancière amounts to objecting that he is not Badiou, in other, it involves a disregard of the singularity of both philosophical projects. The universal is, moreover, one dimension of the emancipatory technics outlined in Disagreement (2004); it is not accurate to suggest that Rancière disregards the universal, though clearly his is not a body of work which speaks in the name of that universal in the totalizing way that Badiou often does. Nor, conversely, can it be accurately subsumed within the endless particularism of US identitypolitical 'activism', as other commentators who shall remain nameless have argued.

ZD: We have been experiencing the covid-19 epidemic for almost two years. Different thinkers write about the virus, the state's actions in the face of the virus, and how we should establish and strengthen our (co-)existence. We see a quiescence in Rancière as a philosopher. What do you think about Rancière's silence about this period we live in?

OD: It is not quite accurate to speak of Rancière's 'silence' about contemporary society. Have you seen his short and very suggestive polemical essay on the storming of the US Capitol and inadequate attempts to analyze it? ${ }^{1}$ But I agree with you that his published work at the moment is more attentive to the political history of aesthetics than it is to the events of contemporary politics. Nevertheless, I think it would be a mistake to presume he somehow should speaking about everything in the way a Sartrean engaged intellectual, or a contemporary commentator, might once have done. These days the airwaves are chock-full of academics offering their 'expert' commentary on current affairs; but Rancière's thought, as you know, involves a fundamental egalitarian questioning of explanatory expertise. His reserve in relation to the epiphenomena of contemporary current affairs seems consistent with that approach. With regard to the public health protection measures taken by governments across the world in response to the ongoing pandemic, it is clear that the overriding biomedical need for these public health measures has also been an opportunity for repressive regimes. Our view of those measures might be inflected by Foucault's discussion of plague containment protocols in Discipline and Punish, for example, but we could also probably just as well see where such measures might tend by looking at what has actually been done in China since the first outbreak, where a mobile phone app now colour-codes individuals according to virus risk, tracks their movements and is used to grant or deny access to public space and resources. Although

\footnotetext{
${ }^{1}$ For the essay: https://www.versobooks.com/blogs/4980-the-fools-and-the-wise
} 
advocates of viral control measures here such as 'vaccine passports' would strongly resist the comparison, what these imply politically is not dissimilar from the sort of radically unequalizing technologies of internal governance already widely adopted in China. In my view, it is time for people to stop imagining that Rancière should have thought and spoken about every subject of significance and to begin using his work in their own autonomous investigations. I have tried to do this in a co-authored book, with Tim Dean, coming out in April of next year: Hatred of Sex. There we adapt Rancière's argument in Hatred of Democracy to talk about the contemporary aversion to sex and, in particular, how bureaucracies of governance use sexual 'inappropriateness' as a form of governing, of policing. But we also bring his work into dialogue with psychoanalysis (Jean Laplanche, in particular) and queer theory, which are both developments that to some extent brush against the grain of his work.

\section{References}

Brown, W. (2015). Undoing the Demos: Neoliberalism's Stealth Revolution. New York: Zone Books.

Davis, O. (2018). “The anti-police of Mai "68 fifty years on" Modern and Contemporary France, 26(2), pp. 107-114.

Davis, O. / Dean, T. (2022). Hatred of Sex (Provocations). Lincoln: University of Nebraska Press.

Foucault, M. (1977). Discipline and Punish: The Birth of the Prison. New York: Pantheon Books.

Graeber, D. (2015). The Utopia of Rules: On Technology, Stupidity, and the Secret Joys of Bureaucracy. New York: Melville House Publishing.

Hallward, P. (2005). "Jacques Ranciere: The Subversion of Mastery" Paragraph, No: 28, pp. 26-45.

Neocleous, M. (2000). The Fabrication of Social Order: A Critical Theory of Police Power. London: Pluto Press.

Rancière, J. (1991). The Ignorant Schoolmaster: Five Lessons in Intellectual Emancipation. Kristin Ross (Trans.). California: Stanford University Press.

Rancière, J. (2004). Disagreement: Politics and Philosophy, Julie Rose (Trans.). MinneapolisLondon: University of Minnesota Press.

Rancière, J. (2006). Hatred of Democracy, Steve Corcoran(Trans.). London: Verso.

Rancière, J. (2016). The Method of Equality (Interviews with Laurent Jeanpierre and Dork Zabunyan). Julie Rose (Trans.). Cambridge: Polity Press. 